\title{
The Atuatanga model: A methodology for researching Māori theology
}

This article will discuss the development of the Atuatanga model and its relevance and application to the exploration, conceptualisation and researching of Māori theology. The word atua refers to an ancestor with continuing influence; or a god, demon, supernatural being, deity, ghost, strange being, or an object of superstitious regard (Moorfield, 2011). While the word atua is commonly translated as 'god', Moorfield (2011) argues that this is a misconception of the original meaning. Tate (2012) maintains that the missionaries took the word atua and used it to describe the Christian God, capitalising the ' $a$ ' in 'Atua' to signify the superiority of the "...the only true God..." (John $17: 3)$.

Adding 'tanga' - a suffix added to nouns to designate the quality of the base noun (Moorfield, 2011) - to the end of the word atua, creates the term Atuatanga. Melbourne (2011) states:

The word has two parts; the first is 'atua', a word to describe spiritual beings (more commonly called gods) which were credited with supernormal powers that could be exercised in helping or opposing people, in the mundane affairs of this life. The second part, 'tanga', is the suffix which speaks about the culture or dealing with everything that has to do with spiritual beings, or 'ngā atua Māori and Te Atua o te Paipera (God of the Bible), and how Māori modified and adapted their understandings to these in their lives (p. 20). 
I define Atuatanga quite simply as "...all things atua" (Rangiwai, 2018c, p. 179). In the context of this work and with regard to my theological thinking generally, Atuatanga pertains to Māori spirituality whether one is referring to atua, Atua, or both. The term Atuatanga will be capitalised throughout, so too the word Atua, to denote the importance of Atua - plural or singular (ngā Atua/te Atua), Māori or Christian - to Māori.

In developing the Atuatanga Model, my theological thinking has been shaped by the theology expressed by Pā Henare Tate (2012) in his Atua, tangata, whenua model. ${ }^{1} \mathrm{He}$ argues that our Māori relationships with Atua, tangata and whenua are "dynamically related" (p. 38) and in fact define who we are. Tate (2012) opines: "If one enhances one's relationship with Atua, also enhanced will be one's relationship with tangata and whenua" (p. 38) and vice versa. He also contends that the same is true if one begins with whenua or tangata as a starting point.

\section{Figure 1: Atua, tangata, whenua model}

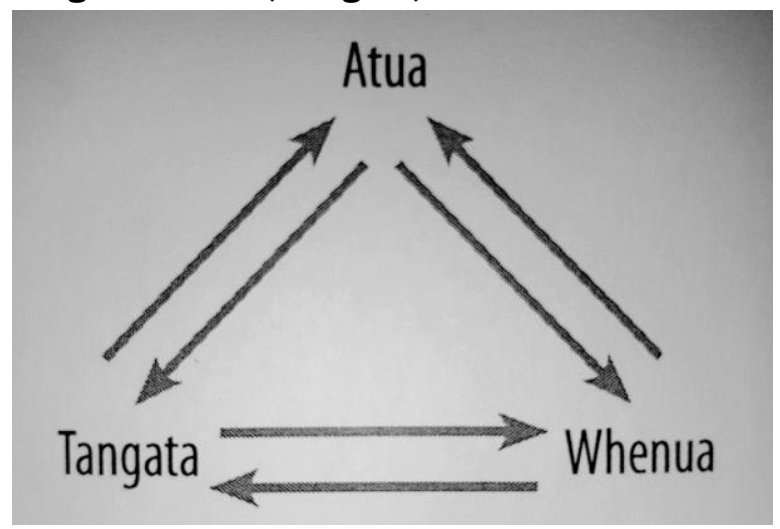

(Tate, 2012, p. 38)

1 Tate (2012) does not refer to this model as a model as such. Rather, the model is part of a sub-section entitled Atua, tangata and whenua (pp. 38-40). 
Like the early missionaries, Tate (2012) uses a/A to distinguish between 'atua' and 'Atua'. He argues that the missionaries were exposed to Māori creation narratives which described the origins of the universe and the place of departmental atua within their various realms over which they possessed dominion. However, he argues that atua were not supreme beings. He states: "The relationship of these spheres of creation to one another appears to be grounded only in the unity of the Creator who brought them into being. The atua relate back to their creator and therefore to one another" (Tate, 2012 , p. 39). Tate (2012) uses the term Atua to name God of the Bible in his work. The word tangata refers to human beings, or to a person. While the term whenua refers to land. For Tate (2012), " $w]$ henua provides sustenance for tangata and all other living creatures. It gives tangata a sense of identity and belonging" (p. 39).

The Atuatanga model draws architecturally and theologically on that of Tate (2012). However, there are significant differences. In the Atuatanga model, there is no distinction drawn between 'atua' and 'Atua'. The term Atuatanga, here, refers to both. The concepts of tangata and whenua are the same as those expressed by Tate (2012), with the exception of an additional meaning to the word whenua, which engenders an important theological consideration. Tate (2012) comments on the importance of land for the provision of sustenance for all life on the earth. However, "[w]henua is a term that means both land and human placenta; the double meaning of this word points to the significance of Māori connections to land" (Rangiwai, 2018f, p. 10). This extra layer of meaning connects Māori to the land genealogically, physically and spiritually as " $[w]$ henua is a cultural concept and cultural reality that concomitantly names land and placenta, and addresses the links between Papa-tū-ā-nuku and Māori" (Rangiwai, 2015, p. 224; see Rangiwai, 2018f, p. 14). Furthermore:

For Māori, the concept of whenua as land and the concept of whenua as placenta are inseparable and 
indubitably convey the fundamental connections of Māori to the environment. The Māori world view reflects the whakapapa relationships of humans and all living things to the primordial parents, Papa-tū-ā-nuku and Rangi-nui, and to each other; everything is connected (Rangiwai, 2018e, p. 73).

\section{Figure 2: Atuatanga mode1 ${ }^{2}$}

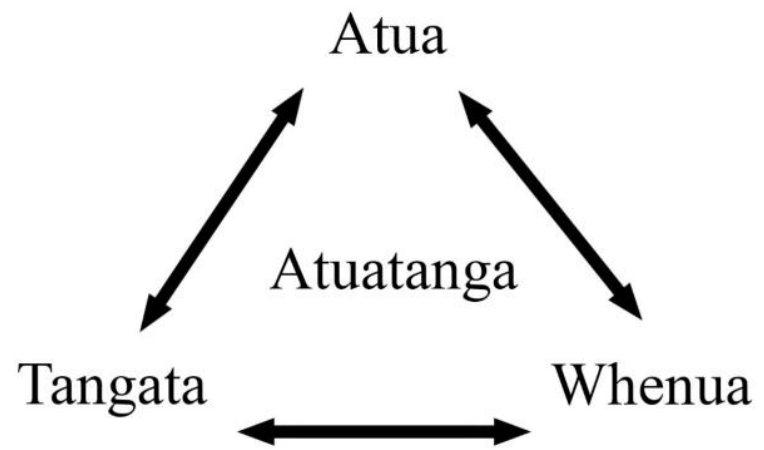

Atuatanga is the central theological concept in this model. The dynamic triangulation of the aspects of this model expresses a Māori theological reality based on the interdependent relationships between Atua, tangata and whenua. Atuatanga has a number of context-dependant definitions spanning across a range of Māori disciplines. This work, however, will highlight only theological definitions of the term from Melbourne (2011) and Hollis (2013).

From a theological point of view Melbourne (2011) describes Atuatanga as: pre-European theology; Māori spirituality; theology from a Māori perspective; and the study of God from

2 I acknowledge Dr Benita Simati-Kumar for making this model at my request. 
a Māori, and particularly, Māori Anglican, perspective - citing the fact that Te Pīhopatanga o Aotearoa, the Māori arm of the Anglican Church, have discussed and used the term Atuatanga to describe Māori theology in their ministry training since the mid-1990s. ${ }^{3}$ Melbourne (2011) argues that one school of thought names Atuatanga as the system of knowledge surrounding the Io tradition - the creator and ruler of all things. This tradition is found in certain iwi and in some parts of the Pacific including Hawai'i, the Society Islands, and the Cook Islands (Moorfield, 2011), but is a topic of debate as some argue that Io is a post-contact response which mirrors the 'supremacy' of the Judeo-Christian God.

Melbourne (2011) opines that many Māori have, since the arrival of Christianity, omitted the beliefs in ngā Atua, believing that these are opposed to those of Christianity. He contends that Atuatanga might be understood as an attempt by some Māori to understand the God of the Bible through Māori understandings, and at the same time, an attempt by others to bring together and reconcile the beliefs of traditional Māori with those of Christianity. Others, he argues, have revived some preChristian traditions with regard to ngā Atua. Melbourne (2011) maintains that the position of Te Pīhopatanga o Aotearoa, with regard to ministry training, has been to "...interweave traditional concepts along with Christian thinking” (p. 27).

Hollis (2013) argues that the term Atuatanga requires careful consideration; in fact, he wrote an entire doctoral thesis around Atuatanga and its potential to hold together the Christian and Māori theological worldviews. He expounds that Atuatanga may refer to the domain over which te Atua or ngā Atua express authority. The term may represent, he claims, the characteristics and the study of ngā Atua or te Atua. He states:

\footnotetext{
${ }^{3}$ Both Hollis (2013) and Melbourne (2011) comment on the fact that Te Pîhopatanga o Aotearoa included Atuatanga as a field of study in their ministry training in the mid-90s, which was the result of a failed attempt, with regard to New Zealand Qualifications Framework accreditation, to use the word 'theology' in a ministry qualification.
} 
"Atuatanga has been equated to the English word theology and some te reo Mãori experts considered it to be the closest word in te reo Mãori to the Greek derivative of [the word] theology" (Hollis, 2013, p. x).

An in-depth literature review around the term Atuatanga is beyond the scope of this article but Hollis' (2013) doctoral thesis entitled, Te Atuatanga: Holding Te Karaitianatanga and Te Mãoritanga together going forward, provides references to a range of different materials that mention or discuss the term, and which show that it is not a new word.

The Atuatanga model is a methodological framework for the exploration, conceptualisation and researching of Māori theology. I have used this model as a means to think about, research, and write about Māori theology. The Atuatanga model was the lens through which I conceptualised, researched and interpreted my theological thinking and which allowed me to access the language necessary to write the following autoethnographic pieces.

\section{Syncretism in Māori theology}

Theology is God talk

A human attempt to

Theorise the Divine

Theology 'from here' and

Theology 'from elsewhere' (Darragh, 2003)

Theology is shaped by context (Tate, 2012)

Through indigenous eyes

Theology can be a platform

From which to rediscover, reclaim...

...reconcile and redefine our spirituality

In a neo-colonial context

As indigenous Māori Christians

Marsden and Ruatara preached 
Jesus' blood mixed with whenua

And a new faith grew in the people

Māori prophets, as responses

To land lost, syncretised

Theologies, Māori and Christian

Innovative frameworks of faith

Developed in the face of devastation

Instilled in our people, a sense of hope

The plea of Māori messiahs all

Was to hold on to the land

To look courageously to the future

Syncretism: a phenomenon where

Indigenisation and Christianisation

Occur simultaneously (Jørgensen, 2013)

One where the power of those who control

Religion is disturbed and disrupted (Goosen, 2000)

Our prophets unsettled Pākehā power!

A deep-seated uncertainty of syncretism

Exists throughout Christian history (Jørgensen, 2013)

And yet the Church has always...

...been infused with local culture (Vilaça \& Wright, 2009)

Gods, spirits, rituals and ceremonies

Melt into one another

Akin to Christ's Mass and Solstice

Our traditions merged, like wearing black

Ringing bells, and blessing headstones

We embraced Christianity

Through the templates

Of our own knowledge (Cooper, 2017)

We 'did' Christianity our way

And we never fully abandoned 
Our former spirituality (Lewis, Willing \& Mullan, 1995)

atua or Atua?

The Christians took our word

And offered it on the altar of the new God

A capitalised'A' to signify

That 'the one true God' is superior

And a small 'a' to denote the 'lesser' (Tate, 2012).

"Māori indigenous theology is

Māori faith seeking Māori understanding.

It is theology developed by Māori for Māori” (Tate, 2012,

p. 21)

"Māori theology is

Ranginui e tū nei,

Papatūānuku e takoto nei"

(W. Te Haara, personal communication)

Māori theology determines

The parameters of our spiritual reality

Where Hinenuitepō and Jesus embrace

Māori theology is atuatanga

Atuatanga is Māori spirituality

Atuatanga is all things atua (Rangiwai, 2018c, pp. 177180).

\section{Mixed-up theology}

Surrounded by karakia

And tears of joy

We come into the world

Surrounded by karakia

And tears of sorrow

We exit the world

Buried in the bosom

Of Papatūānuku

Swaddled lovingly

In Hinenuitepō's kākahu 
Crowned with stars

Plucked from Ranginui's canopy

Flowing, ballooning robes

Frolick and flap about

Darting in between prayers

Hīmene and karakia flow

From one minita to the next

Preaching about Jesus

The radical, love-obsessed Jew

Jesus said

In my father's house

Are many mansions

I'll have one of those, bro

A flash as house would go nicely

With my starry crown and cloak

Jesus can be my father

And Hinenuitepō, my mother

Papatūānuku and Ranginui

My Nanny and Koro

We can all fit inside

One of those mansions

There's lots of room

For everyone...

And their beliefs (Rangiwai, 2018b, pp. 175-176).

“God is...":A personal theology based on stories from my grandmother

God is the pulse of the universe

God is the sunlight piercing the kawakawa leaves

God is the first breath of a pēpi born on a dirt floor

God is the belly of a kererū heavy with miro berries

God is the crackling of wood in the kāuta

God is rēwena bread - te taro o te ora - cooked in the embers

God is mīti tahu reconstituted with pūhā

God is collecting rongoā in the bush to heal the whānau

God is white bread with jam dipped in cream 
God is a chipped enamel mug burning my bottom lip

God is the 'fragrance' of kānga wai bubbling in the pot

God is the eel squirming in the hinaki

God is a full puku after the hākari

God is the taniwha lurking in the river

God is the potato we touch when exiting the urupa

God is the branch the tohunga uses to sprinkle us with

water

God is the marae bell calling us to prayer

God is the tokotoko pointing to Papatūānuku and Ranginui

God is ngā atua Māori in the environment around us

God is the mauri that animates life

God is the wai that negates tapu

God is Koro's grave in Casino

God is the log floating up-stream

God is the faded poppy wreath in the wharenui

God is the sorrow of a broken heart

God is the strains of wailing and tangi

God is the warps and wefts of a whäriki

God is the medals sent home after the war

God is the green lizard scurrying under a rock

God is the aroha of a Nanny for her mokopuna (Rangiwai,

2018a, pp. 171-172)

\section{Tangihanga}

You lie in state

In the wharemate

At Patuheuheu marae

Adorned with a taonga

That I gave to you

A pounamu Hei Tiki

Kahurangi grade - fine, light

And without blemish

Your passing cuts deep

Into my fragile, broken heart

The tears sting my cheeks

The hūpē dries on my black t-shirt

Like the trails of a dozen snails 
Glistening in the summer sun

The grief drains me, vampirically

Like a squirming black, leach

Pulsating and feasting

On the arteries of my aroha

Its sharp mouthpiece gnawing

Intensely and purposefully

Images of you unwell and

Dying, haunt my thoughts

I recall your suffering

Each time I close my eyes

Hospital scenes and last moments

Projected on my eyelids

In High Definition realness

When you made your descent

Beneath Papatūānuku's skin

I watched from afar and wept

Hinenuitepō's embrace

Nor Jesus' promise of heaven

Did little to comfort me

Your chrome nameplate

And myriad plastic flowers

Now mark your resting place

My whānau are my healers

The rongoā for my pain

Their presence and love

This begins the healing

As does the incessant crying

Behind closed doors

When I am alone (Rangiwai, 2018d, pp. 173-174).

The Atuatanga model is a methodological framework for researching and writing about Māori theology. The triangulation and dynamic interaction of Atua, tangata and whenua, as the building blocks of Māori theology, are clearly visible in the ethnographic works above. Atuatanga - all things Atua - is 
weaved throughout each of the pieces, and is punctuated by the interface of Hinenuitepō, Ranginui, Papatūānuku, and Jesus. The Atuatanga model is one that may become a methodology for further scholarly research around the topic of Māori theology, and it is hoped that it may be useful to others in the field. 


\section{References}

Cooper, G. (2017). Gods and Kaupapa Māori research. In T. Hoskins \& A. Jones,

Critical conversations in Kaupapa Māori (pp. 147-159). Wellington, New Zealand: Huia.

Darragh, N. (2003). Contextual method in theology: Learnings from the case of Aotearoa New Zealand. Pacifica: Australasian Theology Studies, 16(1), 45-66.

Goosen, G. (2000). Syncretism and the development of doctrine. Colloquium, 32(2), 137-150.

Hollis, J. T. (2013). Te Atuatanga: Holding Te Karaitianatanga and Te Māoritanga together going forward. Unpublished doctoral thesis, University of Canterbury, Christchurch, New Zealand.

Jørgensen, J. A. (2013). Indigenization, syncretism and the assumed boundedness of Christianity: A critique. In A. Adogame \& S. Shankar (Eds.), Religion on the move! New dynamics of religious expansion in a globalizing world (pp. 99-111). Leiden, Netherlands: Konin klijke Brill NV.

Lewis, J. J., Willing, L. V. \& Mullan, D. S. (1995). Koru and covenant: Reflections on Hebrew and Mãori spirituality in Aotearoa. Orewa, New Zealand: ColCom Press.

Melbourne, T. (2011). Te wairua kōmingomingo o te Māori: The spiritual whirlwind of the Mãori. Unpublished doctoral thesis, Massey University, Palmerston North, New Zealand.

Moorfield, J. C. (2011). Te Aka-Māori-English, English-Māori dictionary. Auckland, New Zealand: Pearson.

Rangiwai, B. (2015). Ko au ko Te Umutaoroa, ko Te Umutaoroa ko au: Toward a Patuheuheu Hapū Development Model. Unpublished doctoral thesis. Auckland University of Technology, Auckland, New Zealand. Retrieved from: https://aut.researchgateway.ac.nz/handle/10292/8851

Rangiwai, B. (2018a). "God is..." : A personal theology based on stories from my grandmother. Te Kaharoa: The eJournal on Pacific and Indigenous Issues, 11(1), 171-172. Retrieved from: https://www.tekaharoa.com/index.php/tekaharoa/article/view/1 $79 / 159$

Rangiwai, B. (2018b). Mixed-up theology. Te Kaharoa: The eJournal on Indigenous and Pacific Issues, 11(1), 175-176. Retrieved from: 
https://www.tekaharoa.com/index.php/tekaharoa/article/view/1 $84 / 161$

Rangiwai, B. (2018c). Syncretism in Māori theology. Te Kaharoa: The eJournal on Indigenous and Pacific Issues, 11(1), 177-180. Retrieved from: https://www.tekaharoa.com/index.php/tekaharoa/article/view/1 $86 / 162$

Rangiwai, B. (2018d). Tangihanga. Te Kaharoa: The eJournal on Indigenous and Pacific Issues, 11(1), 173-174. Retrieved from: https://www.tekaharoa.com/index.php/tekaharoa/article/view/1 $82 / 160$

Rangiwai, B. (2018e). Te Umutaoroa: A model for Patuheuheu hapū development. Te Kaharoa: The eJournal on Indigenous and Pacific Issues, 11(1), 21-100. Retrieved from: https://www.tekaharoa.com/index.php/tekaharoa/article/view/1 76

Rangiwai, B. (2018f). Te Umutaoroa: A Patuheuheu research model. Te Kaharoa: The eJournal on Indigenous Pacific Issues, 11(1), 1-20. Retrieved from: https://www.tekaharoa.com/index.php/tekaharoa/article/view/1 $\underline{69 / 153}$

Tate, H. (2012). He puna iti i te ao märama: A little spring in the World of light. Auckland, New Zealand: Libro.

Vilaça, A. \& Wright, R. M. (Eds.). (2009). Native Christians: Modes and effects of Christianity among indigenous peoples of the Americas. Surrey, England \& Burlington, VT: Ashgate. 